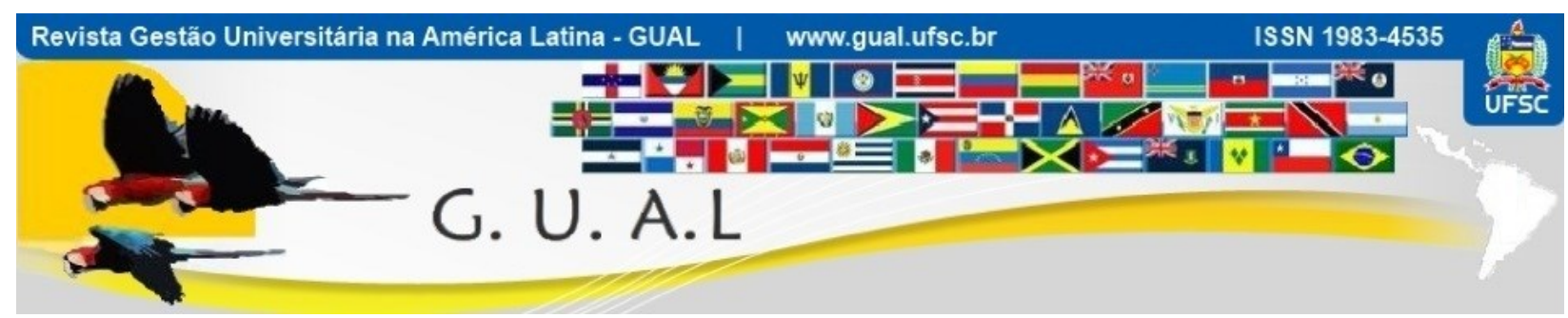

DOI: http://dx.doi.org/10.5007/1983-4535.2019v12n3p45

\title{
PROCESS OF INTERNATIONALIZATION AND REGIONAL DEVELOPMENT: CONSOLIDATION OF A LANGUAGE TEACHING LABORATORY
}

\section{PROCESSO DE INTERNACIONALIZAÇÃO E DESENVOLVIMENTO REGIONAL: CONSOLIDAÇÃO DE UM LABORATÓRIO DE ENSINO DE LÍNGUAS}

\begin{abstract}
Liane Beatriz Rotili, Mestre http://orcid.org/0000-0003-4425-5892 liane.rotili@hotmail.com Universidade Regional do Noroeste do Estado do Rio Grande do Sul | Programa de Pós-Graduação em Desenvolvimento Ijuí | Rio Grande do Sul | Brasil

Nairana Radtke Caneppele Bussler, Mestre https://orcid.org/0000-0002-4928-7300 nacaneppele@hotmail.com Universidade Nove de Julho | Programa de Pós-Graduação em Administração São Paulo | São Paulo | Brasil

Anderson Amaral-Oliveira, Mestre http://orcid.org/0000-0002-3959-6943 anderson.amaral@unijui.edu.br Universidade Regional do Noroeste do Estado do Rio Grande do Sul | Departamento de Humanidades e Educação Ijuí | Rio Grande do Sul | Brasil

Daniel Knebel Baggio, Doutor http://orcid.org/0000-0002-6167-2682 danibaggio@gmail.com Universidade Regional do Noroeste do Estado do Rio Grande do Sul | Programa de Pós-Graduação em Desenvolvimento Ijuí | Rio Grande do Sul | Brasil
\end{abstract}

Recebido em 31/julho/2018

Aprovado em 02/abril/2019

Publicado em 02/setembro/2019

Sistema de Avaliação: Double Blind Review

Revista GUAL, Florianópolis, v. 12, n. 3, p. 45-67, setembro-dezembro 2019 www.gual.ufsc.br 


\title{
RESUMO
}

O objetivo deste estudo é analisar a consolidação de um laboratório de línguas em um processo de internacionalização de uma Instituição de Ensino Comunitária (ICES), como forma de fomentar o desenvolvimento regional. A ICES em estudo atua na região noroeste do estado do Rio Grande do Sul a sessenta anos, e utiliza um laboratório de línguas (LELU) como parte da sua estratégia de internacionalização. Os dados foram obtidos através de entrevista com o coordenador do LELU, e por meio de relatórios da plataforma de ensino de inglês utilizada pela ICES, sendo utilizado o SPSS, versão 21 (Statistical Package for the Social Sciences) para realizar analises estatísticas descritivas e de frequência dos dados coletadas nos relatórios e documentos do laboratório de línguas e dos relatórios da plataforma de inglês online. Como principais resultados evidencia-se a consolidação do LELU no processo de internacionalização da ICES atuando em diversas frentes: ensino de inglês à distância em ambiente virtual, encontros presenciais de conversação e grupos de estudos em inglês, atuando de forma consistente e continua com alunos, bolsistas e professores de diferentes projetos de pesquisa.

Palavras-chave: Internacionalização. Desenvolvimento Regional. Laboratório de Línguas. Ensino Superior.

\begin{abstract}
The objective of this study is to analyze the consolidation of a languages laboratory in the internationalization process of a Community Institution of Higher Education (CIHE) as a way to promote regional development. The CIHE in question has operated in the northwestern region of the Rio Grande do Sul state for sixty years, and it uses a languages laboratory (LELU) as part of its internationalization strategy. Data were obtained through an interview with LELU coordinator and through reports of the English teaching platform used by the CIHE, using SPSS, version 21 (Statistical Package for the Social Sciences) to perform descriptive statistical analyses and determine the frequency of the data collected in reports and documents from the languages laboratory as well as reports of the online English platform. The main results show the consolidation of LELU in the process of the CIHE internationalization operating on several fronts: distance learning in a virtual environment, classroom-based lessons and study groups in English, working consistently and continuously with students, professors and scholarship holders from different research projects.
\end{abstract}

Keywords: Internationalization. Regional Development. Languages Laboratory. Higher Education 


\section{INTRODUÇÃO}

Geographical distances, different languages and cultures can no longer be considered barriers to the internationalization of people and community institutions of higher education $(\mathrm{CIHE})^{1}$ that promote regional development. At the beginning of the $21^{\text {st }}$ century, it was possible to identify some changes regarding higher education in Brazil that aimed to promote the production and dissemination of knowledge, considering several measures for this, among them, the increase of the academic mobility at the international level.

Internationalization can be understood as the set of tendencies for the intensification of the global relations of interaction and exchange, the global interconnection of the fields of social communication and the harmonization of social models and structures (SCHRIEWER, 1995). For Luhmann, (1975, p.57), "in evolutionary terms, it is a totally new phenomenon". The relationship between internationalization and social interaction benefits societies, education and professionals seeking work models and aggregate knowledge through relations with other cultures; consequently, it develops the place where they are applied.

Therefore, academic mobility adds value to the intellectual and cultural capital of universities and students, allowing not only experiences, but also the flow of information and knowledge, sharing and bringing transformations to the reality of the social groups that are permeated by student and university action.

A language teaching laboratory represents a differential and qualified space in the academic environment that allows the experience of a linguistic, cultural and institutional process in transformation. In addition to a physical space, a languages laboratory fundamentally represents the dialogical opening of a predominantly monolingual culture to a world of knowledge, of human intellectual production on an international scale, using the English language as empowering factor for these exchanges.

Thus, the objective of this study is to analyze the institutional consolidation of a languages laboratory in the process of internationalization of a CIHE as a way to promote regional development. From this perspective, the research is based on themes of the process of internationalization of the higher education, university language teaching laboratory, the internationalization process and regional development. After describing the methodological processes used, the results are analyzed and, ultimately, the final considerations are presented

\footnotetext{
${ }^{1}$ The abbreviation CIHE refers to the community institutions of higher education in accordance with Federal Law No. 12,881 / 2013 (BRAZIL, 2016).
} 
along with suggestions for future research.

\section{THEORETICAL REFERENCE}

\subsection{INTERNATIONALIZATION PROCESS OF HIGHER EDUCATION}

The internationalization of higher education in recent decades has presented changes in relation to complexity, volume and reach, taking a leading position globally. However, this process is associated with different stages and forms of motivation in different countries. According to Lima and Contel (2008: 21), "the process of internationalization of higher education is on the agenda of the leaders of Brazilian CIHEs, both public and private." Regarding the resources for the realization of such movement, Franco (2002, p.313) justifies that:

[...] it can be said that resources are increasingly scarce for two reasons: a) at international level, it is believed that in the current stage of Brazil's development, the country cannot remain as a priority on the agenda of international cooperation agencies; and (b) at national level, the Brazilian government has been increasingly critical in the granting of international scholarships, because it understands that the country's postgraduate programs are already at a high stage of maturity, and that few research projects would justify the investment required.

According to Krawczyk (2008: 45), the university's internationalization policies "are mainly in the field of International Cooperation of different governmental institutions for the development of human resources for higher education and for scientific and technological development". The Coordination for the Improvement of Higher Education Personnel (CAPES) is linked to the Ministry of Education (MEC), and it has an international cooperation program whose objective is to develop Brazilian postgraduate activities in the global context, to support Brazilian research groups through international exchange, seeking excellence in the postgraduate pursuits. These actions are coordinated by the International Relations Board (IRB) (CAPES, 2017).

The main activity of CAPES International Cooperation occurs through bilateral agreements, programs that promote joint research projects between Brazilian and foreign groups. CAPES sponsors work missions (exchange of professors), scholarships (exchange of students) and a cash amount to support the project activities. It is imperative that the Brazilian research groups be linked to postgraduate programs recognized by MEC, preferably with concepts 5, 6 or 7 in the last CAPES evaluation (CAPES, 2017). For Krawczyk (2008, p. 45) 
"although these institutions have been created with these specificities, today, they are much more tenuous, developing both research development policies and human resources training."

The CIHE studied, in its Institutional Development Plan (IDP), 2015-2019, foresees an internationalization policy encouraging actions to strengthen the relationship with other educational institutions abroad, enabling students' access to scientific developments and the exchange of knowledge through academic mobility that happens through partnerships with international institutions around the world. The possibilities of exchange and improvement in English are managed by the Office of International Affairs, linked to the Rectory, which assists students interested in these experiences.

As foreseen in its IDP, one of the major challenges of the CIHE for the next few years is the internationalization of university action. Currently, the main initiatives have involved academic mobility, either by sending or receiving foreign students. This stage requires an institutional strengthening that involves the establishment of partnerships with international institutions mostly from the lines of research of stricto sensu programs, which allows the densification of results of the joint researchers and the increase of teaching mobility. The CIHE also adheres to the government programs encouraging internationalization.

It is understood that the English language is the universal channel of communication between countries and one of the most commonly used languages in the world. Promoting the teaching and the development in this language constitutes another strategy adopted by the CIHE for its internationalization. Therefore, two initiatives are implemented to allow the English language learning: to promote the development of English language courses and to establish the institutional subsidy so that the internal public could take the courses.

As a way to meet this demand, the course "English on Campus" was developed by the Letters Course and its Language Teaching Laboratory, subsidized institutionally, not aiming to obtain profit in its operation. In this way, holders of scientific and technological initiation, teaching, and extension scholarships, as well as other students, professors and staff, may have easier access. It is important to emphasize that enrollment in English courses became compulsory for the students linked to scholarship programs, either in the institutional program, in others of their preference or that they have a level of proficiency already attested.

\subsection{UNIVERSITY LANGUAGE TEACHING LABORATORY}

The language teaching laboratories are spaces specially constituted in their material 
and human resources to provide the study, practice and intensive experience of the target language. Thus, these bodies become necessary in universities that wish to take the lead in their internal and external actions, as producers and disseminators of knowledge, in their native and foreign languages. An institutional linguistic openness is considered a two-way street, both disseminating and receiving the flow of production and knowledge of global referents.

According to Santos (1999), the dynamics of relationships and the democratization of access to a universe of information have changed with the emergence of information and communication technologies (ICT). At times, the contemporary society may be called “information society" (WERTHEIN, 2000) as well as "knowledge society", regarding the critical knowledge in the face of this universe of information, education and training processes (LÉVY, 1999). With respect to the democratization of access to this universe of information, Castells (2006) states that an average of $97 \%$ of the planet's information is digitalized and that $80 \%$ of this information is available for internet access.

A university language teaching laboratory operates by different actions: through teaching, acting in the theoretical and practical training of students of the Letters Course in their native and foreign languages, enabling students to get in touch with different realities of their future field of professional activity; in research, problematizing theoretical and practical aspects of the teaching and the functioning of the languages, cultures and literatures, proposing advances in terms of accumulated knowledge; and in the university extension, in order to share with the academic and external community the results of their research and experiments, offering innovation, practice through teaching actions, continuing education and provision of services.

In the teaching context, the university languages laboratory offers the following as university extension activities to the public: language courses (general purpose English, English for Specific Purposes and English for Academic Purposes - EGP / ESP / EAP), online and classroom-based lessons, Spanish speaking groups with volunteer exchange students, guided reading groups, proficiency/sufficiency courses in Spanish/English, English-language studies for Specific and Academic Purposes (ESP / EAP) and revision and translation of academic researches.

The courses and classroom-based activities offered, like conversation groups, have a communicative approach as their theoretical basis (RICHARDS, 2006; RICHARDS, 
RODGERS, 1999), but this does not mean the teaching of grammar competence does not occur, as learners are exposed to meaningful language samples. For Vygotsky (2007), learning is an active process that occurs either interpersonally or internally, and the subject acts on the environment at hand, starting from a mediation of what the subject already knows and what the subject is able to learn.

Considering the involvement of language teaching with the use of technological resources, the university offers online English courses with the possibility of further classroom-based study in the languages laboratory. The literature refers to blended learning (GARRISON; KANUKA, 2014) as a powerful opportunity to combine online teaching with classroom-based practices, enhancing both dimensions and providing a more effective language acquisition. The online course is based primarily on reading skills development, understood as indispensable to higher education students.

According to Nuttal (1996), the process of understanding written texts and reading models can be bottom-up or top-down. A bottom-up model prioritizes text processing, working with the text structures. As readers make little or no use of the context and their knowledge of the world, it will be difficult for them to synthesize the main ideas (KATO, 1999). In top-down processing, unlike in the previous model, the text is no longer the focus, and non-visual information becomes the priority. Reader use their intelligence and experience, making use of inferences (NUTTAL, 1996), and, according to Kato (1999), it makes readers fluent, swift, because of the guesswork use, allowing them to easily understand the general and main ideas of the text. Goodman (1967) advocates reading as a psycholinguistic game of guesswork, involving interaction between thought and language, making accurate perceptions and identification of all textual elements unnecessary. Smith (1989) also emphasizes the reader's role and states that the important thing is to combine visual information with nonvisual knowledge. Fluent readers have enough orthographic information assimilated and tend to skip unfamiliar words. Rumelhart's (1977) interactive model combines their linguistic knowledge and previous knowledge, integrating bottom-up and top-down models; in other words, each reader must analyze both the microstructural and macrostructural aspects of the text.

In this way, the development of activities that unite different dimensions of scholarly action, such as the initial training of language teachers, the university extension, provision of services, and the scientific research, allows the languages laboratory to be central to the 
university's development as a plurilingual and multicultural environment, expanding and perfecting its action, opening its geopolitical frontiers by means of the linguistic exchange and culture of knowledge.

\subsection{INTERNATIONALIZATION PROCESS AND REGIONAL DEVELOPMENT}

Education and culture came to be conceived as an integral part of citizenship, and they became citizens' rights after social revolutions of the twentieth century. With this change, the university became a social institution, inseparable from the idea of democracy and democratization of knowledge (BERNHEIM, 2008). Regarding the quality and effectiveness of these institutions, Douglass (2010, p.15) states that:

Brazilian university has been rapidly advancing in quality and effectiveness in all areas, partly due to the continued support of federal and state governments, but also because there is a growing perception that Brazil needs a quality network in universities of research for its economic development.

Panizzi (2006) emphasizes that education, as well as being strategic for the development of nations, is a right, as presented at the Conference on Higher Education (CHE), in the Paris declaration. LDB $n^{\circ} 9.394$ / 96 describes in Article 43 that higher education has as purpose:

I - to stimulate the cultural creation and the development of scientific spirit and reflective thinking; II - to train undergraduates in different areas of knowledge, make them apt for insertion in professional sectors and for participation in the development of Brazilian society, and collaborate with their ongoing training; III - to encourage the work of scientific research, aiming at the development of science and technology and the creation and diffusion of culture, and thus, to develop the understanding of man and the environment in which he lives; IV - to promote the dissemination of cultural, scientific and technical knowledge which constitutes the patrimony of humanity and to communicate knowledge through teaching, publications or other forms of communication; $\mathrm{V}$ - to raise the permanent desire for cultural and professional improvement and enable the corresponding concretization, integrating the knowledge that is being acquired in a systematizing intellectual structure of the knowledge of each generation; VI - to stimulate knowledge of the problems of the present world, especially national and regional ones, to provide specialized services to the community and to establish a reciprocal relationship with it; VII - to promote the extension, open to the participation of the population, aiming at the diffusion of the achievements and benefits resulting from the cultural creation and the scientific and technological research generated in the institution. VIII - to act in favor of the universalization and improvement of the basic education through training and qualification of professionals, the realization of 
pedagogical researches and the development of extension activities which approximate the two school levels. (BRAZIL, 1996)

Therefore, based on the assumption that the CIHEs are fulfilling their purposes, it is understood that scientific knowledge contributes with emphasis to the development of the economy, culture, society and research as a systematic process of knowledge construction, and has the ability to generate new knowledge or systematize existing knowledge (NOGUEIRA, 2000). In relation to the internationalization of higher education, Knight (2012) states that it was from globalization that positive and negative influences arose, and although the two processes are fundamentally different, there is a close link between them, both providing and generating the development and they are inevitable.

Murphy (1999) describes the positive impacts of internationalization through three mechanisms: the distribution of global knowledge and technology, the uniformity of quality standards, and the transfer of complementary ideas to countries embarking on new political, economic, and social projects. Therefore, this process is not only limited to the exchange of the related parties, but it must act through an articulating process, providing innovations and development.

\section{METHODOLOGY}

This study was constituted as social research with a pure research purpose. A research plan of descriptive nature with a quantitative and qualitative approach was used, so, regarding the technical procedures, the strategy applied, bibliographical, documentary and field research elements.

The goal of the study was to analyze the consolidation of a languages laboratory in the internationalization process of a CIHE as a way to promote regional development. First, bibliographical research was carried out by means of the selection of national and international relevant studies on the theme. This phase had the purpose of providing support to the discussion of the phenomenon studied. Parallel to this, an interview was carried out with the coordinator of the languages laboratory and with the CIHE international relations adviser who was in charge at the beginning of the process, in 2012, as well as documentary research through the reports of the online English platform. Data related to academic mobility were obtained from the reports of the International Relations Office of the CIHE for the years 2014, 2015 and 2016. 
In order to analyze the information collected in the reports and documents of the languages laboratory and the reports of the online platform, the software Microsoft Excel 2010, Statistical Package for the Social Sciences - SPSS, version 21, and Statistical Analysis System - SAS, version 9 have been used. Analyses of frequency and descriptive statistics (averages and standard deviations) were performed. These findings are triangulated with the interviews and with the theoretical reference, generating the results and discussions of the next section.

\section{RESULTS AND DISCUSSION}

The analysis of the results is divided in six blocks. Firstly, the languages laboratory of the CIHE studied is characterized; in the second block, the first part of the English teaching project, called English on Campus, is analyzed; in the third stage, the second part of the project, the online English course, is analyzed; in the fourth block, the English reading groups; in the fifth stage, the conversation groups; and, finally, the students who went on exchange programs.

\subsection{CHARACTERIZATION OF THE LANGUAGES LABORATORY OF THE CIHE STUDIED}

The university languages laboratory exists as a practice environment of the Letters Course of the institution. However, since 2013, it has been understood in a different way by the university administration team, considering the elaboration of the PDI 2015-2019 and the view of internationalization. Thus, the institutional consolidation of this environment arises from the necessity of qualifying the projects of research professors and scholarship holders. Research carried out by professors and students with a focus on English for Specific Purposes and its divulgation in the courses of Business, Economics and Accounting pointed out difficulties regarding the language and the needs involving the ESP in particular. Another factor which fostered the implantation of this project was the midiatic divulgation, on a national scale, that students from the program Science Without Borders were returning from their exchange programs, losing their scholarships and missing great study opportunities abroad due to not obtaining the proficiency levels required by the program.

Under the administration of Vice Chancellor for Research, University Extention and Postgraduate Studies (VRPGPE), the Letters Course - Portuguese and English of the university became in charge of the pedagogical organization of the course, selecting the 
materials and didactic strategies to be used, providing formation to its professors, planning and discussing the new teaching approaches and the role of technologies in this process. A department of the institution with know-how in the organization of courses of different natures assumed the course management, also carrying out the logistics and the documentary organization. The International Relations Office of the institution provided support as well, helping with the divulgation and application of the leveling tests to the students, and by being a place of reference and support to the students with regards to exchange programs and other issues on academic mobility.

Considering these demands, the university, through its Institutional Development Plan, defines among its objectives the intensification of the stimulus to the scientific production in national and international journals of major relevance, expanding also the participation in the national scientific community and in the constitution of international exchange program networks, making necessary the proposal of solutions to keep ahead of the challenges. The PDI 2015-2019 predicts total subsidy to the realization of the English course on campus for students holding a scientific or technological initiation, teaching or extension scholarship and the opening of non-profit English courses for professors, other students and staff interested in their personal and academic enhancement.

In order to diagnose the English level of the students who hold a scientific or technological initiation scholarship, judicious leveling tests were applied, in the second semester of 2014, to 91 students; an abyss was found between their level of English and the needs of academic everyday life, with the Common European Framework of Reference for Languages (CEFR) as a parameter, created by the European Commission (CAMBRIDGE, 2011, p. 8).

In table 1, data show that even after years of English in elementary and high school and, in some cases, previous attendance to free English courses, the proficiency level of the students is still insufficient for their needs. In a brief analysis, approximately $80 \%$ of the CIHE students in 2014 were in levels A1 and A2, which refer to basic users of the language, and about $20 \%$ were intermediate users, that is, independent speakers but yet without a full development and communication through the language, reflection processes and more critical readings. Advanced proficient users who are able to perceive more complex and implicit meanings, with a wider range of vocabulary and grammatical awareness, were not diagnosed among the respondents. 
Table 1 English level of CIHE students in the second semester of 2014

\begin{tabular}{|l|c|c|c|c|}
\hline \multicolumn{2}{|c|}{$\begin{array}{c}\text { English level classification } \\
\text { (CEFR, 2011) }\end{array}$} & $\begin{array}{c}\text { Number of students } \\
(\mathrm{n})\end{array}$ & Students frequency (\%) & $\begin{array}{c}\text { Cumulative students } \\
\text { frequency (\%) }\end{array}$ \\
\hline Beginner & $\mathrm{A} 1$ & 16 & 17.6 & 17.6 \\
\hline Elementary & $\mathrm{A} 1+$ & 56 & 61.5 & 79.1 \\
\hline Pre-intermediate & $\mathrm{A} 2$ & 0 & 0 & 79.1 \\
\hline Intermediate & $\mathrm{B} 1$ & 7 & 7.7 & 100 \\
\hline $\begin{array}{l}\text { Upper- } \\
\text { intermediate }\end{array}$ & $\mathrm{B} 2$ & 12 & 13.2 & 100 \\
\hline Advanced & $\mathrm{C} 1$ & 0 & 0 & \\
\hline
\end{tabular}

Source: Authors (2017).

Institutional Development Plan of the CIHE establishes among its objectives the intensification of the stimulus to the scientific production in national and international journals of major relevance while expanding the participation in the national scientific community and in the constitution of international exchange program networks, the study aimed to propose solutions to keep ahead of the challenges.

Figure 1 illustrates how LELU relates to activities of promotion of linguistic and cultural practices, meeting different demands from the academic community in their respective complexity levels, through the promotion of study and through the certification of the proficiency reading level.

Figure 1 University Languages Laboratory

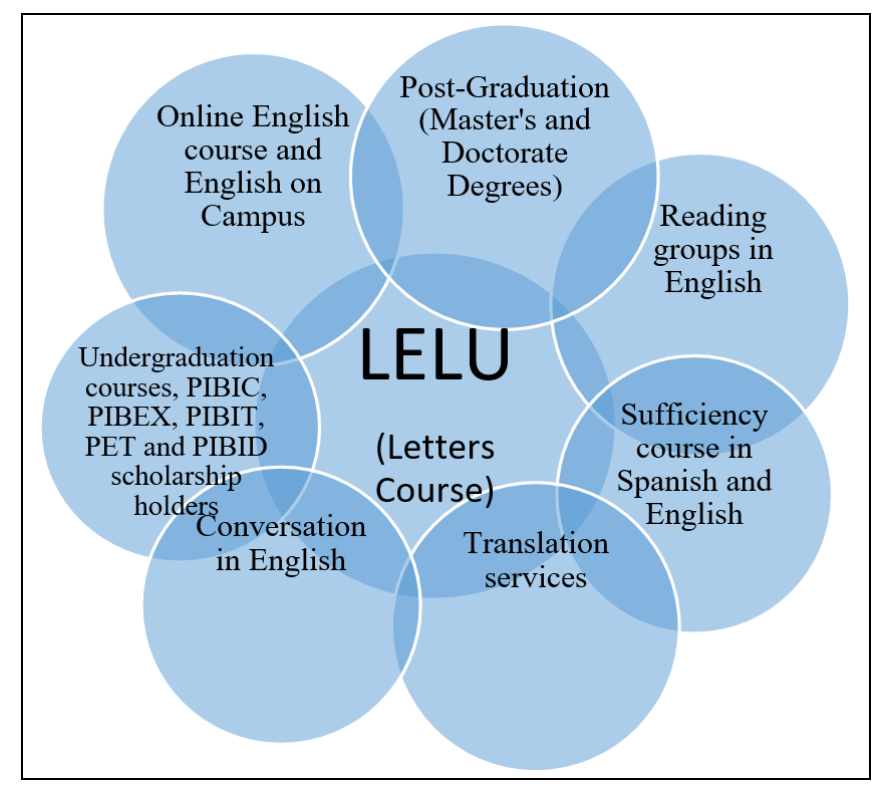

Source: Authors (2017).

LELU relates to the community in different ways through its courses and directed activities: with the undergraduate courses and their students, compulsorily with the 
scholarship holders, with postgraduate courses, and with professors and staff.

\subsection{ENGLISH ON CAMPUS}

English on Campus was the first project of dissemination of English via LELU and the Letters Course - English/Portuguese. The proposal was a course directed at undergraduate and postgraduate students, professors and employees of the CIHE, aiming to potentialize this range of learners with their diverse knowledge, helping them to constitute themselves as subjects through another language and another culture, and consequently, acquiring a new linguistic repertoire which allows the oral and written communication and the negotiation of new meanings with prior knowledge.

The course is made up of five biannual modules, in a total of 300 hours distributed in modules of 60 hours per semester, with experience of real situations of communication and use of the language, following the communicative approach of language teaching (ALMEIDA FILHO, 1993) through teaching materials specifically designed for the development of oral (listening and speaking) and written (reading and writing) skills.

After the fifth module (or even before finishing it), the student may continue their studies through the English for Academic Purposes Course, which is offered by the institution, or even the course of Academic Reading in English, offered biannually, which may be taken concomitantly. This is justified by the communicative objectives and needs of the public, which see English on Campus as directly related to courses of English for General Purposes (EGP), something which certainly should be complemented and perfected in subsequent courses directed to the many academic areas (BHATIA, 2014).

Besides the students of scientific and technological initiation, the course English on Campus opened to new groups so that professors and collaborators of the institution could invest in their careers. Taking into consideration the collaborators' shortages of time, the course is propositional in a way that groups of at least ten students may suggest the days of the week and the times which best suit their availability, organized according to the possibilities of the teachers involved in the course.

Thus, according to table 1 , in the year of the course implementation alone, the program English on Campus provided 91 students with the opportunity to study English in the second semester of 2014. 72 of them were scholarship holders with total exemption of the course costs, purchasing only the textbook. Additionally, the students with a scholarship of 
scientific and technological initiation carried out their English studies within the workload designated to activities covered by the scholarship.

According to a survey done with class record books in the years of 2014 and 2015, there was an absence rate of $22 \%$. Considering that the course was made up of 60 hours per semester, it means that the students from English on Campus took on average 47 hours of classroom-based lessons per semester.

In table 2, the English course had 127 enrolled students, and the number of scholarship holders had an increase of $14 \%$, making 82 the number of scholarship holders who studied English in the first semester of 2015. In addition, 45 students who were part of the staff, professors and fee paying students disbursed about one minimum wage per semester to qualify their English.

Table 2 English level of the CIHE students in the first semester of 2015

\begin{tabular}{|l|c|c|c|c|c|c|c|c|c|c|c|}
\hline \multirow{2}{*}{$\begin{array}{c}\text { English level classification } \\
\text { (CEFR, 2011) }\end{array}$} & \multicolumn{9}{|c|}{\begin{tabular}{c} 
First Semester of 2015 \\
\cline { 3 - 15 }
\end{tabular}} & $\begin{array}{c}\text { Scholarship } \\
\text { holders }\end{array}$ & \multicolumn{2}{|c|}{ Staff } & \multicolumn{2}{|c|}{ Professors } & \multicolumn{2}{|c|}{ Others } & \multicolumn{4}{c|}{ Total } \\
\cline { 3 - 15 } & $\mathrm{Nr}$ & $\%$ & $\mathrm{nr}$ & $\%$ & $\mathrm{nr}$ & $\%$ & $\mathrm{Nr}$ & $\%$ & $\mathrm{nr}$ & $\%$ \\
\hline Elementary & $\mathrm{A} 1+$ & 30 & 2.6 & 4 & 3.1 & 8 & 6.3 & 14 & 11.0 & 56 & 44.1 \\
\hline Pre-intermediate & $\mathrm{A} 2$ & 0 & 0,0 & 0 & 0.0 & 0 & 0.0 & 0 & 0.0 & 0 & 0.0 \\
\hline Intermediate & $\mathrm{B} 1$ & 43 & 33.9 & 4 & 3.1 & 1 & 0.8 & 8 & 6.3 & 56 & 44.1 \\
\hline $\begin{array}{l}\text { Upper- } \\
\text { intermediate }\end{array}$ & $\mathrm{B} 2$ & 9 & 7.1 & 0 & 0.0 & 0 & 0.0 & 6 & 4.7 & 15 & 11.8 \\
\hline Advanced & $\mathrm{C} 1$ & 0 & 0.0 & 0 & 0.0 & 0 & 0.0 & 0 & 0.0 & 0 & 0.0 \\
\hline Total & & 82 & 64.6 & 8 & 6.3 & 9 & 7.1 & 28 & 22.0 & 127 & 100.0 \\
\hline
\end{tabular}

Source: Authors (2017).

The total subsidy for the realization of the English course on campus for holders of scientific, technological, teaching and extension scholarships remained in the second semester of 2015, as well as the automatic enrollment for the next term. With this, the number of scholarship holders enrolled increased in 10\%, growing from 82 to 90 students, according to table 3. As for students who were staff members, professors and fee paying students, the number decreased from 45 to 13 . Three reasons were pointed out for this decrease: the difficulty in renewing the subscription (all the process was manually done); the lack of divulgation; and, the value charged relative to the costs, despite the fact it was a non-profit English course. 
Table 3 English level of CIHE students in the second semester of 2015

\begin{tabular}{|c|c|c|c|c|c|c|c|c|c|c|c|}
\hline \multirow{3}{*}{\multicolumn{2}{|c|}{$\begin{array}{l}\text { English level } \\
\text { classification } \\
\text { (CEFR, 2011) }\end{array}$}} & \multicolumn{10}{|c|}{ Second semester of 2015} \\
\hline & & \multicolumn{2}{|c|}{$\begin{array}{l}\text { Scholarship } \\
\text { holder }\end{array}$} & \multicolumn{2}{|c|}{ Staff } & \multicolumn{2}{|c|}{ Professor } & \multicolumn{2}{|c|}{ Others } & \multicolumn{2}{|c|}{ Total } \\
\hline & & $\mathrm{nr}$ & $\%$ & $\mathrm{nr}$ & $\%$ & $\mathrm{nr}$ & $\%$ & $\mathrm{nr}$ & $\%$ & $\mathrm{nr}$ & $\%$ \\
\hline Elementary & $\mathrm{A} 1+$ & 43 & 41.7 & 3 & 2.9 & 0 & 0.0 & 0 & 0.0 & 46 & 44.7 \\
\hline $\begin{array}{c}\text { Pre- } \\
\text { intermediate }\end{array}$ & A2 & 0 & 0.0 & 0 & 0.0 & 0 & 0.0 & 1 & 1.0 & 1 & 1.0 \\
\hline Intermediate & B1 & 30 & 29.1 & 0 & 0.0 & 0 & 0.0 & 2 & 1.9 & 32 & 31.1 \\
\hline $\begin{array}{c}\text { Upper- } \\
\text { intermediate }\end{array}$ & B2 & 17 & 16.5 & 0 & 0.0 & 5 & 4.9 & 1 & 1.0 & 23 & 22.3 \\
\hline Advanced & $\mathrm{C} 1$ & 0 & 0.0 & 0 & 0,0 & 0 & 0.0 & 1 & 1,0 & 1 & 1.0 \\
\hline Total & & 90 & 87.4 & 3 & 2.9 & 5 & 4.9 & 5 & 4.9 & 103 & 100.0 \\
\hline
\end{tabular}

Source: Authors (2017).

From this context raised the idea of offering online classes the next year, aiming to reduce costs and facilitate enrollment, attending to a bigger number of students. In 2016, English on Campus closed down, and the activities of English via online platform began.

\subsection{ENGLISH VIA ONLINE PLATFORM}

The online English teaching platform modifies the dynamic of English teaching because, according to Santos (1999), the ICTs (Information and Communication Technologies) permit the democratization of access to a universe of information. Castells (2013) claims that an average of $97 \%$ of the information on the planet is digitalized and that $80 \%$ of this information is available on the internet.

The online English course has been chosen through a partnership between the CIHE studied and COMUNG (Consortium of Community Universities of Rio Grande do Sul) with the objective of complementing the English studies of students, professors and staff from institutions of a similar profile. The users of this platform may take the course using a desktop, tablet or smartphone, and they make use of content in accordance with their proficiency level. Furthermore, the online studies are complemented with classroom-based activities at LELU, through conversation groups and directed studies. Doubt clarification sessions are also offered so that the students can better adapt to the digital platform, developing their autonomy.

The course has 15 levels (from basic to advanced), and the communication, e-mails, exercises and conversation classes, in all levels, are in English. In 2016, the online course had 
a total of 533 students, 299 enrolled in the first semester and 298 in the second semester. From these, 64 remained in the program from one semester to the next, that is, $22 \%$ of the students remained enrolled in the course. Among the main reasons for non-permanence are the termination of scholarship contracts and the completion of the undergraduate course.

In table 4 , it is possible to observe that the rate of Beginner and High Beginner students in the first semester was $67.5 \%$, while in the second semester there was a slight drop to $65.1 \%$, confirming the lag in the English level of the students at the CIHE.

Table 4 Frequency analysis of the online English course in 2016

\begin{tabular}{|c|c|c|c|c|c|c|}
\hline \multirow{2}{*}{$\begin{array}{c}\text { English online } \\
\text { course } \\
2016\end{array}$} & \multicolumn{3}{|c|}{ First Semester } & \multicolumn{3}{c|}{ Second Semester } \\
\cline { 2 - 7 } & Frequency & Percentual & $\begin{array}{c}\text { Cumulative } \\
\text { percentage }\end{array}$ & Frequency & Percentual & Cumulative percentage \\
\hline Beginner & 97 & 32.4 & 32.4 & 118 & 39.6 & 39.6 \\
\hline High Beginner & 105 & 35.1 & 67.5 & 76 & 25.5 & 65.1 \\
\hline Low Intermediate & 25 & 8.4 & 75.9 & 40 & 13.4 & 78.5 \\
\hline Intermediate & 47 & 15.7 & 91.6 & 43 & 14.4 & 92.9 \\
\hline High Intermediate & 12 & 4.1 & 95.6 & 5 & 1.7 & 94.6 \\
\hline Low Advanced & 7 & 2.3 & 97.9 & 3 & 1 & 95.6 \\
\hline & 6 & 2 & 100 & 13 & 4.4 & 100 \\
\hline Total & 299 & 100 & & 298 & 100 & \\
\hline
\end{tabular}

Source: Authors (2017).

In the first semester of 2016 there were 299 enrollments. From the $265(88.3 \%)$ students who did at least one activity in the portal, the student who did the fewest activities did two of them, and the one who did the most activities, did 2,282. It has also been observed that 35 students (11.7\%) did not do any activity. Yet, according to table 5, there were students who dedicated less than one hour to the studies, whereas the student who dedicated the most time used the portal for 83 hours.

In the second semester of 2016, there were 298 enrollments. From the $225(75.5 \%)$ students who did at least one activity, the student who did the fewest activities was one activity and the one who did the most, did 1,650 activities. It has been observed that 73 students $(24.5 \%)$ of those who enrolled in the course did not do any activity. Yet, according to table 5, there were students who dedicated less than one hour to study, whereas the student who dedicated the most time used the portal for 61 hours. 
Table 5 Descriptive analysis of the online English course 2016

\begin{tabular}{|c|c|c|c|c|c|c|}
\hline \multicolumn{2}{|c|}{ Online English course 2016 } & N & Minimum & Maximum & Average & $\begin{array}{c}\text { Standard } \\
\text { deviation }\end{array}$ \\
\hline \multirow{3}{*}{ First semester } & Hours of study & 269 & 0 & 83 & 6.2 & 80.7 \\
\cline { 2 - 7 } & Activities & 265 & 2 & 2282 & 170.4 & 215.6 \\
\cline { 2 - 7 } & Activities & 225 & 1 & 1650 & 101.3 & 179.1 \\
\hline
\end{tabular}

Source: Authors (2017).

This scenario confirms the interest deficit of a part of the CIHE students regarding the improvement of their English, while some students take advantage of the opportunity and reach high levels of dedication and knowledge of the English language. It is also possible to observe that the tools of distance learning and information and communication technologies are products which, because they reach a wider population, form a heterogeneous public with big differences.

In table 5, it can also be observed that in the first semester the students dedicated an average of six (6.2) hours to study English in the online platform and did an average of 170.4 activities, whereas in the second semester the students dedicated an average of four (4) hours and did an average of 101.3 activities.

\subsection{CONVERSATION AND STUDY GROUPS IN ENGLISH}

LELU makes available to the academic and external community the participation in conversation and study groups in English and Spanish from the proposition of a provocative text: spoken, written or media. In addition to the students enrolled in the online English course, students of many undergraduate courses, professors and members of the external community participate, forming groups with similar fields of study and proficiency levels.

\subsection{READING GROUPS IN ENGLISH}

In 2017, LELU, in partnership with the departments of Master's and Doctoral Degrees of the CIHE, started to form groups of students interested in reading papers and materials in English. The objective was to carry out readings of specific content for the courses utilizing the interactive model of Rumelhart (1977), which links linguistic knowledge and previous knowledge, integrating bottom-up and top-down models; that is, reading which analyzes both the microstructural and the macrostructural aspects of the text.

The students are instructed about strategic reading in English to perform firstly a 
reading utilizing skimming, or a general understanding, where they "pass their eyes" and observe title, headings, figures, graphics, tables, etc. In the second phase, they read utilizing scanning, understanding the most important parts of the text according to the author. In the third phase, they read the text in full, negotiating the meanings of the text with previous knowledge, extrapolating the proposed meanings, going from their world knowledge to the knowledge obtained through the reading, broadening the world knowledge of the reader.

Some departments of the CIHE carry out meetings of scholarship holders with LELU tutors aiming to prepare the students to read papers in English, so that they can use this material in their studies and in the preparation of papers about the projects they take part in.

\subsection{EXCHANGE PROGRAMS ABROAD}

In 2014, 17 undergraduate students and 5 postgraduate students took part in exchange programs abroad. Besides, 15 students (undergraduate and postgraduate) went on study tours abroad and 1 undergraduate student did a practical internship in Germany, according to table 6. In addition to that, about 22 professors of the institution performed activities abroad. The foreign students received were: 4 undergraduate students and 3 Master's Degree students. In 2014, about 14 foreign professors performed activities at the CIHE.

In 2015,13 undergraduate students and 5 postgraduate students took part in exchange programs abroad, according to table 6 . A bachelor student from Germany enrolled as a special student in the second semester in the Master's Degree in Development. In 2015, many foreign professors carried out activities at the CIHE.

In 2016, 12 undergraduate students took part in exchange programs and practical internships abroad and more than 60 students participated in research and events abroad, according to table 6 . The CIHE received 4 foreign students: one from Angola enrolled as regular student; one from Colombia for a Master's Degree; and two students from Germany. Besides, the CIHE received and carried out activities with a group of 32 students from the University of Innsbruck, Austria. In 2016, many foreign professors performed activities at the CIHE, as well as many professors from the CIHE performed activities in foreign institutions. 
Table 6 Undergraduate students who went on exchange programs

\begin{tabular}{|c|c|c|c|c|c|c|c|c|}
\hline \multicolumn{3}{|c|}{2014} & \multicolumn{3}{|c|}{2015} & \multicolumn{3}{|c|}{2016} \\
\hline \multicolumn{3}{|c|}{ Bilateral agreements } & \multicolumn{3}{|c|}{ Bilateral agreements } & \multicolumn{3}{|c|}{ Bilateral agreements } \\
\hline Country & Period & $\begin{array}{c}\text { Quantity } \\
\text { of } \\
\text { students }\end{array}$ & Country & Period & $\begin{array}{c}\text { Quantit } \\
\text { y of } \\
\text { students }\end{array}$ & Country & Period & $\begin{array}{c}\text { Quantit } \\
\text { y of } \\
\text { students }\end{array}$ \\
\hline Portugal & 6 months & 7 & Spain & 6 months & 2 & Australia & 10 months & 1 \\
\hline Poland & 6 months & 2 & Poland & 12 months & 3 & Egypt & 3 months & 1 \\
\hline \multicolumn{3}{|c|}{ Science Without Borders } & Portugal & 6 months & 3 & Poland & 6 months & 4 \\
\hline $\begin{array}{c}\text { German } \\
\mathrm{y}\end{array}$ & 16 months & 1 & Portugal & 12 months & 2 & Portugal & 6 months & 6 \\
\hline $\begin{array}{c}\text { Australi } \\
\text { a }\end{array}$ & 14 months & 1 & \multicolumn{3}{|c|}{ Unibral I - Capes/Daad } & & & \\
\hline Spain & 12 months & 1 & $\begin{array}{c}\text { German } \\
\mathrm{y}\end{array}$ & 12 months & 2 & & & \\
\hline USA & 18 months & 1 & \multicolumn{3}{|c|}{ Program } & & & \\
\hline USA & 17 months & 1 & Portugal & 6 months & 1 & & & \\
\hline USA & 12 months & 2 & & & & & & \\
\hline Hungary & 12 months & 1 & & & & & & \\
\hline \multicolumn{2}{|c|}{ Total } & 17 & & tal & 13 & \multicolumn{2}{|c|}{ Total } & 12 \\
\hline
\end{tabular}

Source: Authors (2017).

In 2014, eight students were sent abroad through the program Science Without Borders by the Federal Government in the last notice providing vacancies. From 2015 on, students only went on exchange programs through bilateral agreements and paying for their expenses.

\section{FINAL CONSIDERATIONS}

This study had as a goal to analyze the consolidation of a languages laboratory in the internationalization process of a Community Institution of Higher Education (CIHE), as a way to promote the regional development. The results evidenced LELU's consolidation in the internationalization process of the institution, at a time when there is a continuous process of projects being developed, acting on several fronts: teaching English through an online course, conversation meetings, reading groups in English, with continuous and consistent action with students, scholarship holders and professors from different courses.

The data collected in this study should be used by the CIHE to assist the direction of the next actions in the internationalization project. The average of class hours per semester of the classroom-based English on Campus (47 hours) and of the online platform (6.2 and 4 hours), suggest the adoption of a third stage of blended English teaching (blended learning), 
with classroom-based and online classes. As a way to optimize the use and participation in the online English course by the students, some measures are recommended: minimum number of participation in compulsory classes at LELU with flexible hours; participation in at least 40 hours of online activities per semester as a criterion for scholarship renewal, considering the English language study as an inherent activity of the benefit; inclusion of postgraduate students in the list of people favored by the institutional subsidy for participation in the online English course; mass diffusion of the distance learning course and LELU's English course to all incoming students at the university, developing an institutional culture of English study and practice in order to provoke a radical change in the learner profile of the institution.

With the shutdown of Science Without Borders in 2017, exchange programs were hampered by the lack of scholarships for students studying abroad, but there are projects of private organizations, awarding students who stand out in the academic world with scholarships. Investing in the English language teaching for students and mainly scholarship holders from the CIHE research projects will allow greater academic mobility, greater exchange of information and qualification of the researches carried out in the institution, promoting the innovation and development of the CIHE region.

This research provided the CIHE studied with the necessary data for self-evaluation, an indispensable tool for the recognition of its strengths and weaknesses. The process of internationalization presents itself as a strategy to improve the teaching quality, the research and the university extension. Thus, rather than an attempt to raise indexes that could lead to a greater international projection, it is an investment aiming to strengthen its relations with the community in which it is situated through an integral human formation.

For future studies, a survey is suggested to verify the proficiency levels of the academic community, as well as their interests and viability to dedicate themselves to the study of a second language, considering this broader sample and monitoring the English language use by the research projects attached to the institution, as these programs contribute directly to the production of knowledge and to the development of the region in which the researched CIHE acts. 


\section{REFERENCES}

ALMEIDA FILHO, J. C. P. (1993): "Dimensões comunicativas no ensino de línguas", Pontes.

ALMEIDA, V. P. (2012): "Conhecendo as regras do jogo: a competência comunicativa e os manuais didáticos de ensino de inglês como língua estrangeira”, Brasília, Universidade de Brasília (Tese de Doutoramento).

BERNHEIM, C. T. (2008): "Desafios da universidade na sociedade do conhecimento: cinco anos depois da conferência mundial sobre educação superior”, Brasília, UNESCO.

BHATIA, V. K. (2014): “Analysing genre: Language use in professional settings”, Routledge.

BRASIL (2016): “Lei no 12.881, de 12 de novembro de 2013”. Dispõe sobre a definição, qualificação, prerrogativas e finalidades das Instituições Comunitárias de Educação Superior ICES, disciplina o Termo de Parceria e dá outras providências, disponível em:

https://www.planalto.gov.br/ccivil_03/_Ato2011-2014/2013/Lei/L12881.htm>, acesso em: 30 dez. 2016.

BRASIL (2017): "Lei n 9.394, de 20 de dezembro de 1996". Estabelece as diretrizes e bases da educação nacional, disponível em: http://www.planalto.gov.br/ccivil_03/leis/L9394.htm>, acesso em: 12 abr. 2017.

CAMBRIDGE ESOL (2011): "Using the CEFR: Principles of Good Practice”, Cambridge, University of Cambridge ESOL, 2011, p. 8.

CAPES (2017): “Coordenação de Aperfeiçoamento de Pessoal de Nível Superior”.

Desempenha papel fundamental na expansão e consolidação da pós-graduação stricto sensu (mestrado e doutorado) em todos os estados da Federação, disponível em: < http://www.capes.gov.br/>, acesso em: 26 abr. 2017.

CASTELLS, M. (2006): “A galáxia da internet: reflexões sobre a internet”, os negócios e a sociedade, tradução de: BORGES, M. L. X. de A, Rio de Janeiro, Zahar.

DOUGLASS, J. (2010): “A internacionalização das universidades vista por três especialistas estrangeiros", Publicada originalmente no Jornal da Unicamp, Revista Ensino Superior Unicamp, (12).

FRANCO, M. E. D. P. (2002): “A educação superior no Brasil”, Porto Alegre, CAPES/ IESALC.

GARDNER, R. C. (1999): "Motivation and second language acquisition".

GOODMAN, K.S. (1967): "Reading: A psycholinguistic guessing game”, Literacy Research and Instruction, (6), (4), p. 126-135.

KATO, M. A. (1999) “O aprendizado da leitura”, 5 a. ed. 
KNIGHT, J. (2012): “Cinco verdades a respeito da internacionalização”. Knight é professora adjunta do Ontario Institute for Studies in Education, Universidade de Toronto, Revista de Ensino Superior da UNICAMP.

KRAWCZYK, N. R. (2008): “As políticas de internacionalização das universidades no Brasil: o caso da regionalização no Mercosul”, Jornal de Políticas Educacionais, (4), pp. 41-52, jul./dez.

LÉVY, P.(1999): “Cibercultura”, Rio de Janeiro, Editora 34.

LIMA, M. C.; CONTEL, F. B. (2008): “Características atuais das políticas de internacionalização das instituições de educação superior no Brasil”, Revista E-Curriculum, (3), (2), p. $1-25$, jun.

LUHMANN, N. (1985): “Soziologische Aufklarung 2”, Opladen: Westdeutscher,p.51-71:Die Weltgesellschaft.

MURPHY, M. (1999): "Experiences in the internationalization of education: Strategies to promote equality of opportunity at Monterrey Tech", Higher Education, (53), (2), p. 167-208, fev.

NOGUEIRA, M. das D. P. (org.) (2000): "Extensão universitária: diretrizes conceituais e políticas”, Fórum Nacional de Pró-Reitores de Extensão das Universidades Públicas, Belo Horizonte: UFMG.

NUTTAL, C. (1996): “Teaching reading skills in a foreign language”, Hong Kong, Macmillan Heinemann.

PANIZZI, W. M. (2006): “Cooperação internacional: solidariedade e diálogo entre iguais?” In: GAZZOLA, A. L. A.; ALMEIDA, S. R. G., Universidade: cooperação internacional e diversidade, Belo Horizonte, Editora UFMG.

RICHARD, J. (2006): “Communicative language teaching today”, Cambridge, CUP.

RICHARDS, J.; RODGERS, T. (1999): “Approaches and methods in language teaching”, Cambridge, CUP.

ROBY, W. B. (2004): "Technology in the service of foreign language teaching: The case of the language laboratory", in: D. Jonassen (Org.) Handbook of Research on Educational Communications and Technology. 2nd ed. p. 523-541, disponível em:

$<$ http://www.aect.org/edtech/19.pdf $>$, acessado em: 25/02/2017.

RUMELHART, D. E. (1994): “Toward an interactive model of reading”, International Reading Association.

SANTOS, B. de S. (1999): "Pela mão de Alice: o social e o político na pós modernidade", 5. ed., São Paulo, Cortez. 
SAVIGNON, S. J. (1991): “Communicative Language Teaching: State of the Art", TESOL Quarterly, (25), (2), (Summer), p.261 -277.

SCHRIEWER, J. (1995): "Sisterna mundial e inter-relacionamento de redes: a internacionalização da educação e o papel da pesquisa comparativa", Revista Brasileira de Estudos Pedagógicos, (76) (182/183), p. 1-64.

SMITH, Frank. (1989): “Compreendendo a leitura: uma análise psicolingüística da leitura e do aprender a ler".

UR, P. (2012): “A course in English language teaching”, Cambridge, CUP, 2 ed.

VYGOTSKI, L. S. (1999): “A formação social da mente”, 7. ed., São Paula, Martins Fontes.

WERTHEIN, J. (2000): “A sociedade da informação e seus desafios”, publicado em: 04/2000, disponível, acesso em: 02/03/2017. 